\title{
Groundwater Treatment in Rungkut Sub-District, Surabaya
}

\author{
Setyo Budi Kurniawan ${ }^{\mathrm{a}}$, Ipung Fitri Purwanti ${ }^{\mathrm{a}}$, Bieby Voijant Tangahu ${ }^{\mathrm{a}}$, Harmin Sulistyaning \\ Titah $^{\mathrm{a}}$ and Sarwoko Mangkoedihardjo ${ }^{\mathrm{a}}$
}

${ }^{a}$ Laboratory of Environmental Remediation, Department of Environmental Engineering ITS, Surabaya, Indonesia

\begin{abstract}
Results of Environment agency laboratory test show the Surabaya's clean water which still meet quality standards by the year 2008 reached $97.5 \%$ and decreased to $58.2 \%$ in 2009 . Rungkut is one of the sub-districts in Surabaya where people fulfill their daily water by using well water or ground water. Nowadays, people feel their well water is not feasible in use for everyday needs anymore. This was due to the decreased quality of well water because the contamination of organic matter. These community services activities try to help Rungkut Sub-District people in meeting their water needs. Efforts will be preceded by a hearing, sampling groundwater at some point, and test the quality of the groundwater. The results of groundwater quality test obtained will be used to create a water treatment unit which can be operated simply by the community. Based on the groundwater quality test obtained, the pilot scale unit of groundwater treatment designed and installed using multiple tray aerator and carbon active filter combination. Multiple tray aerator installed for 3 steps of aeration and the carbon active filter contains $60 \%$ (volume by volume) carbon active media.
\end{abstract}

Keywords: Clean Water Treatment; Groundwater quality; Rungkut Sub-District

\section{Background}

Clean water is a vital necessity for mankind. Every day, clean water needed for drinking, cooking, bathing, washing and other purposes. By using clean water, people can avoid some kind of disease. Clean water is also much needed by the industry. Clean water is needed as a raw material by many industries. However, the amount of clean water decreased as pollution increased.

Many water pollutions occurred in the neighborhood. Because of too many pollutants, nature loses its ability to restore to its original condition. The loss of the ability of nature is what causes the scarcity of clean water quantity available in nature. Water pollution caused by many factors. Factors that much effect to the pollution are the entry of garbage, organic substances and inorganic substances into water bodies.

Contaminated water can cause many problems for mankind. Health problems is the major nuisance that can arise from contaminated water problem. Other problems such as economic and aesthetic problems can also arise due to water contamination. Health problems that often arise due to the use of polluted water are diarrhea and skin diseases. Because of the many disorders that can be caused, the water pollution problems need to be solved soon.

Rungkut sub-district is a region located on the east coast of Surabaya. Rungkut sub-district surrounded by Rungkut industrial area. Along with the rapid development of the industry in this region, clean water has always been a problem. Clean water problem much felt by people whose income is insufficient to fulfill clean water from PDAM. Contaminated water are still used by the community for the purpose of bathing, washing and other needs except drinking and cooking. The use of contaminated water can certainly lead to health problem, it can even cause death. Therefore, it is necessary to make a water treatment that is both simple and easy to implement on public.

\section{Objective and Advantage}

Objectives to be achieved was helping communities to apply a simple ground water treatment. The benefit of this activity was to get clean water that meet the health standard requirements.

\section{General Research Area Description}

Rungkut district is a part of Surabaya East region which has an area of $\pm 21.08 \mathrm{~km}^{2}$ and divided into six sub-districts, they are Kali Rungkut, Rungkut Kidul, Medokan Ayu, Wonorejo, Penjaringan Sari, and Kedung Baruk. In topography, Rungkut is located at a height of 4.6 meters above sea level with an average rainfall of $189.2 \mathrm{~mm}$ per month. According to Surabaya Central Bureau of Statistics (2014), the population of Rungkut District in 2013 reached 111.945 inhabitants with a population density of 5,325 inhabitants $/ \mathrm{km}^{2}$. The Rungkut District administrative boundaries are mentioned below:

North : Mulyorejo District

South : Rungkut District

East : The Madura Strait

* Corresponding author. Tel.: +62-89-7272-0606.

E-mail address: setyobudi.kurniawan@gmail.com 
West : Gubeng District

\section{Methods}

\subsection{Hearings}

This activity was done by inviting community representatives from all sub-districts in Rungkut. This activity was carried out once in order to solicit opinions from the public about the quality of ground water in their residence. Hearing activity held in the Central of Rungkut District on May 22, 2015. Participants of this event were representatives from each village in Rungkut District. The main objective of this activity was to capture the aspirations and problems that exist in society about groundwater.

Hearings activity has identified some of the problems complained by the public about the quality of groundwater, namely:

1. Difficulty in obtaining non PDAM clean water Trouble on getting non PDAM clean water in most residential areas were caused by pollution. Contaminants cause odor and discoloration in groundwater.

2. Difficulty in obtaining clean water during the dry season

Difficulty in obtaining clean water during the dry season was one of the problems complained by the public. This problem was caused by many rain water catchment land-use as a residential. This condition was exacerbated by the presence of contamination in well water.

\subsection{Socialization activities}

This activity was done by inviting community representatives from all sub-districts. This activity has been performed twice in order to provide information about pilot water treatment activities that will be conducted by ITS team which begins with taking groundwater samples at several locations. The first socialization activities carried out in the Central of Rungkut District on June 28, 2015. This event was attended by community representatives from all sub-districts in Rungkut District. The main agenda of this activity was to provide a description of the groundwater sampling activities to be conducted by ITS team.

The second socialization activity was held in the Central of Rungkut District on August 12, 2015. This event was attended by community representatives from all sub-districts. The main agenda of the second socialization was to give an explanation about pilot scale of ground water treatment.

\subsection{Groundwater Sampling}

Water quality samplings were done randomly on six-point location. Sampling was performed three times. Sampling were done, first, at the beginning of the event to get the early quality of ground water. The second and third are for groundwater quality monitoring after the installation of groundwater treatment unit. Groundwater sampling sites were mentioned below:

\section{Wonorejo RW 01}

2. Medokan Ayu RW 09

3. Rungkut Kidul RW 01

4. Rungkut Kidul RW 02

5. Rungkut Kidul RW 03

6. Rungkut Kidul RW 03 '

\subsection{Groundwater Quality Test Results}

Parameters tested for the quality of shallow groundwater include chemical and physical parameters that refer to PERMENKES No. 492 of 1990 on drinking water quality requirements. Taken four parameters that were considered to represent groundwater quality condition were $\mathrm{COD}, \mathrm{pH}$, salinity and turbidity. Water quality tests conducted at the Laboratory of Environmental Management, Department of Environmental Engineering. Based on the sampling location that has been determined, then the ground water quality test results from each location can be seen in Table 1. 


\begin{tabular}{ccccc}
\hline Sampling Location & $\mathbf{C O D}\left(\mathbf{m g} / \mathbf{L} \mathbf{O}_{2}\right)$ & $\mathbf{p H}$ & Salinity $\left(\boldsymbol{\%}_{\mathbf{o}}\right)$ & Turbidity(NTU) \\
\hline Wonorejo RW 01 & 11,00 & 7,00 & 0.52 & 1.65 \\
Medokan Ayu RW 09 & 19,00 & 6,75 & 1.29 & 7.35 \\
Rungkut Kidul RW 01 & 8,00 & 7,15 & 1.15 & 4.35 \\
\hline Rungkut Kidul RW 02 & $\mathbf{6 0 , 0 0}$ & $\mathbf{7 , 2 0}$ & $\mathbf{0 . 6 3}$ & $\mathbf{1 2 . 5 0}$ \\
\hline $\begin{array}{c}\text { Rungkut Kidul RW 03 } \\
\text { Rungkut Kidul RW 03 }\end{array}$ & 4,00 & 7.25 & 0.88 & 1.15 \\
\hline
\end{tabular}

Based on the test results of water quality (Table 1) and the results of discussions with the Rungkut District citizen, then the Rungkut Kidul RW 02 selected as the location for further research. This location chosen as the place for placing pilot scale water treatment unit because of some beneficiaries (This was a boarding school with a student registered of about 300 people), the availability of land, and the willingness of school owner to participate, maintain and keep the water treatment unit. Thus, the water quality of wells in RW 02 was tested in more detail. Results of Rungkut Kidul RW 02 well water test in more detail were listed in Table 2.

\begin{tabular}{cccc} 
Table 2. Water Quality Test Result for Rungkut Kidul RW 02 & & \\
\hline Parameter & Unit & Result & Method \\
\hline $\mathrm{pH}$ & - & 7,20 & $\mathrm{pH}$ meter \\
$\mathrm{TSS}$ & $\mathrm{mg} / \mathrm{L}$ & 20,00 & Gravimetric \\
Turbidity & $\mathrm{NTU}$ & 12,50 & Turbidimeter \\
Salinity & $\% / 00$ & 0,63 & Salinometri \\
COD & $\mathrm{mg} / \mathrm{LO}_{2}$ & 60,00 & Reflux/ tetrimetri \\
BOD & $\mathrm{mg} / \mathrm{L} \mathrm{O}{ }_{2}$ & 38,00 & Winkler \\
Surfactant & $\mathrm{mg} / \mathrm{L} \mathrm{LAS}$ & 0,52 & Spektrofotometri \\
Fe & $\mathrm{mg} / \mathrm{L} \mathrm{Fe}$ & 0,33 & Spektrofotometri \\
Mn & $\mathrm{mg} / \mathrm{L} \mathrm{Mn}$ & 1,55 & Spektrofotometri \\
& & & Multi tube \\
Total Coliform & MPN/100 mL & 130.000 & fermentation \\
\hline
\end{tabular}

\subsection{Laboratory Experiments}

It was known that the levels of organic, $\mathrm{Fe}$ and $\mathrm{Mn}$ present in well water samples was fairly high in which location a pilot scale will be placed. The type of treatment used to reduce the levels of organic, Fe and $\mathrm{Mn}$ is a combination of the aeration and activated carbon adsorption [1]. Calculation of water discharge will be processed at the site were:

$\mathrm{Q}=$ Consumption $\mathrm{x}$ Number of Consumers

$\mathrm{Q}=50 \mathrm{~L} /$ person-day $\times 150$

$\mathrm{Q}=7500 \mathrm{~L} /$ day

$\mathrm{Q}=0.000086 \mathrm{~m} 3 / \mathrm{s}$

Based on the processing debit, then a simple tool used to test ground water treatment process on a laboratory scale created. Debit taken was $100 \mathrm{ml} / \mathrm{s}$, that will be created by using a water pump. In accordance with previous planning, then a series of simple water treatment contain multiple tray aeration process and activated carbon filtration created.

Debit replication in the laboratory created by using drinking water pump with a debit $100 \mathrm{ml} / \mathrm{s}$. These pumps will be connected directly from the source of water samples taken from wells at the site. 
The water coming out of the pump directly connect with tray aerator replica. Tray aerator replica was made by using perforated metal tray with a $0.2 \mathrm{~cm}$ hole diameter. This replica was taken because it was considered to represent the form of a tray aerator that will be used on the real pilot scale. After the water passes through the tray aerator replica, water will be dropped as high as $100 \mathrm{~cm}$ or 1 meter to make room for the oxygen to be dissolved in water. High fall-out have been selected for scaling up that can be done later when the results obtained do not meet quality standards. The water then passes through the activated carbon filter. Activated carbon filter was made using a simple tube that is $60 \%$ filled with active carbon.

Based on the results of laboratory testing and theoretical calculations, a sketch of pilot scale of simple drinking water treatment was created. Pilot scale planned to consist of multiple tray aerator and activated carbon filtration. The sketch of pilot scale to be built on the site can be seen in Figure 1.

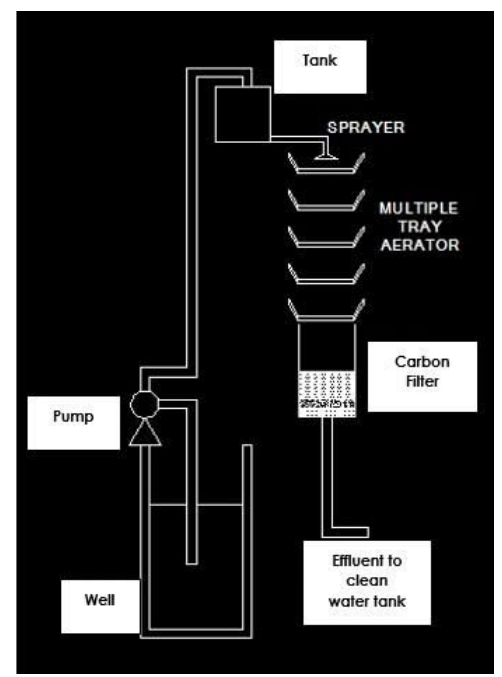

Figure 1. Sketch of Simple Water Treatment Unit

Pilot scale groundwater treatment unit designed and installed using multiple tray aerator and carbon active filter combination. Multiple tray aerator installed for 3 steps of aeration (Figure 2a). Carbon active filter contains 60\% (Volume by volume) carbon active media. The arrangement of filter media from bottom to top is gravel media, carbon active (Jacoby 2000, Japan) and sand media (Figure 2b).

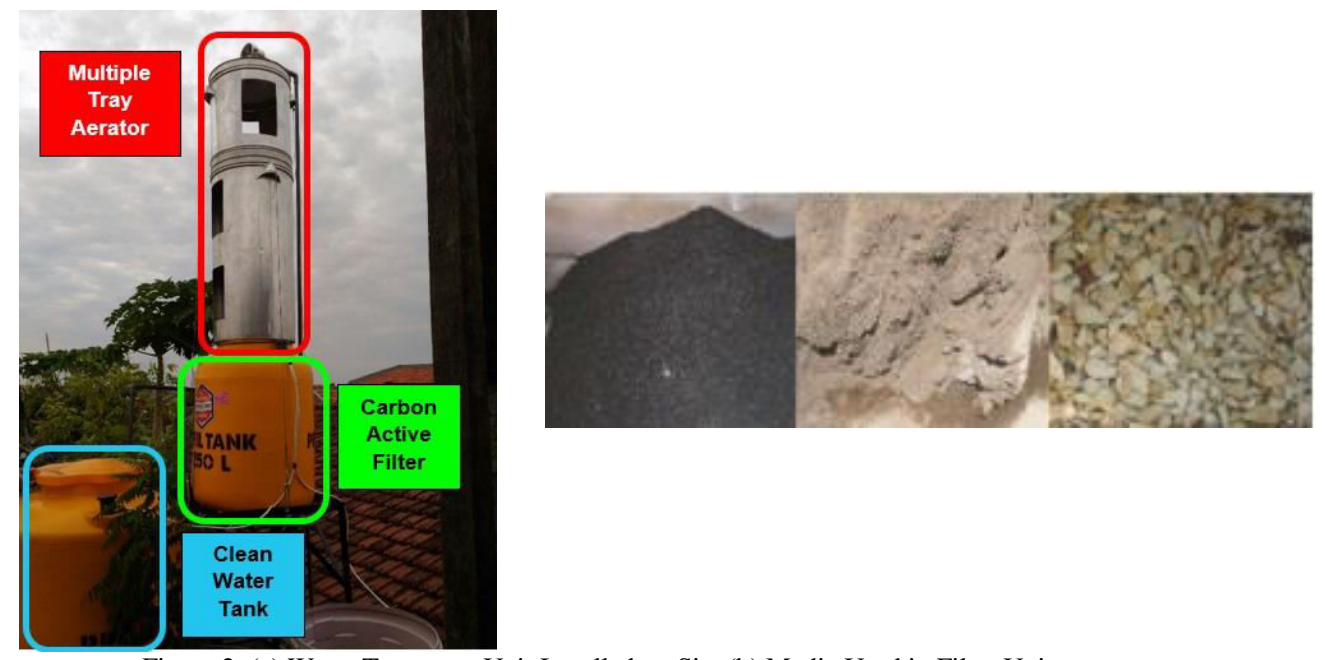

Figure 2. (a) Water Treatment Unit Installed on Site (b) Media Used in Filter Unit 


\section{Conclusions}

- Main problem complained by Rungkut District communities is about discoloration and odor in their well water

- Highest COD tested from well water occurred in Rungkut Kidul RW 02 Sub-District

- Pilot scale groundwater treatment unit installed at Pondok Pesantren Al-Azhar, Rungkut Kidul RW 02 Sub-District

- Pilot scale groundwater treatment unit designed and installed using multiple tray aerator and carbon active filter combination

\section{References}

[1] A. Masduqi and A. Abdu F., Operasi dan Proses Pengolahan Air. Surabaya: ITS Press, 2012. 